\title{
Improving students' reading comprehension ability of Descriptive text through Mind Mapping strategy at the first grade of MTSN 1 Bandarlampung
}

\author{
Fathia Rahmania $^{1}$, Ujang Suparman ${ }^{2}$, Rafista Deviyanti ${ }^{3}$ \\ Universitas Lampung, Jl. Prof. Dr. SoemantriBrojonegoro No. 1, Bandar Lampung ${ }^{1,2,3}$ \\ ${ }^{1}$ Correspondence e-mail: fathiarahmania98@gmail.com
}

\begin{abstract}
The objectives of this research were to find out whether there is any significant difference of the students' reading comprehension at the first grade of MTsN 1 Bandar Lampung before and after the implementation of mind mapping strategy and to find out the students' responses on the implementation of mind mapping strategy at the first grade of MTsN 1 Bandar Lampung. The design used was one group pretest posttest. The subject of the research was the first-grade students of MTsN 1 Bandar Lampung. VII C was chosen as the experimental class and VII D was chosen as the control class. The instrumen were reading test and questionnaire. The data were in form of scores taken from pretest and posttest. The result indicated that there was an improvement of students' reading ability viewed from the pretest to posttest score (30.72 to 57.82) after they had been taught using mind mapping technique. Besides, a set of questionnaire was used to find out the students' responses toward the mind mapping technique. It was found that majority of the students had positive responses toward the mind mapping technique. Thus, it can be concluded that Mind Mapping technique facilitates the students to improve their reading ability.
\end{abstract}

Keywords: Mind Mapping Technique, reading ability, students' responses

\section{INTRODUCTION}

English, as a foreign language in Indonesia, is learned by the students from primary school to university. In English learning, they are expected to master four English skills which include listening, speaking, reading and writing.

One of the most important skills to master is reading comprehension ability (Grabe,2009; Suparman, et al 2020a; Suparman, et al 2020b; Suparman, et al 2020c). According to Grabe (2009), reading is a strategy process that a number of the skills and processes are needed on the part of the reader to anticipate text information, select key information, organize and mentally summarize information, monitor comprehension, repair comprehension breakdowns, and match comprehension output to reader goals. Comprehension is the essence of reading and the active process of constructing meaning from text (Durkin, 1993). Comprehension depends not only on characteristics of the reader, such as prior knowledge and working memory, but also on language processes, such as basic reading skills, decoding, vocabulary, familiar with the text structure, inferencing, and motivation.

Mikulecky (2011) states that reading is a complex conscious and unconscious mental process in which the reader uses a variety of strategies to reconstruct the meaning that the author is assumed to have intended, based on data from the text and from the reader's prior knowledge. 
According to Corbett (1983), descriptive text is one of the expository writing. The description draws a picture, tries to convey the sound, taste and smell of things or objects. Kane (2000) states descriptive text is meaningful text that describes the experience related to the senses, such as what shape, sound, taste is. Most descriptive text is about visual experience, but in fact experience other than the sense of sight, we an also use it to make descriptive text.

Mind mapping strategy is supported by Buzan (2000), Buzan (2006), and Ingemann (2008). The first, according to Buzan (2000) mind mapping is an application that gives us the meaningful information to understand in a simple way. The second Buzan (2006) states mind mapping is the best tool to help our brains to think regularly. Mind mapping can help students easily remember things they represent. The last, according to Ingemann (2008) mind mapping is one of media can develop their ability in memorizing, brainstorming, learning, as well as creativity.

In another research, Amalia (2008) the objective of her study is to find out the effectiveness of using mind mapping in improving students' reading comprehension achievement. It is a preexperimental study which use random sampling in getting the sample. The collecting data is only through the test. The result indicates that using mind mapping in teaching reading comprehension is effective to improve student's reading comprehension achievement. It can be seen from the result of pre-test and post-test; the average score of pre-test $=12.6$ and the standard deviation $=8.88$. Meanwhile, the average score of post-test $=21.7$ and the standard deviation $=9$.

Thus, in her study, the researcher will focus on the Mind Mapping strategy. The differences between the previous researches and this research are about the type of the text, participants, and location of this research. Therefore, this research is entitled "Improving Students' Reading Comprehension Ability of Descriptive Text through Mind Mapping strategy".

Therefore, based on the background above, this study was urgent to conduct to prove that the technique was useful to improve students' reading ability and also to find out students' responses towards this technique.

\section{METHODS}

To conduct this study, the researcher applied a quantitative approach which used one group pretest and posttest (T1 X T2) to answer the first research question and a qualitative approach which used close-ended questionnaire to answer to the second research question. The population of this research was the first-grade students of MTsN 1 Bandar Lampung. The sample of the research was VII C class consisted of 31 students.

The data were collected through pretest and posttest. The pretest was administered to find out the students' reading ability before giving the treatment, and the posttest was administered to know the improvement of students' reading ability after giving the treatment. In addition, the questionnaire was conducted to find out the students' responses after being taught by using Mind Mapping technique. 
After obtaining the scores of pre-test and post-test, the researcher analyzed the data using Iteman (Suparman, 2011; Suparman2019) to determine the reliability, level of difficulty, discriminating power quality of key answers and distractors; besides, Statistical Package for Social Science (SPSS) was also usedto calculate the mean scores of the pre-test and post-test as well as the normality of the data. The normality of the test is used to determine if the data was set well-modeled by a normal distribution and to compute how likely it was for a random variable underlying the data set to be normality distributed. More operationally, the data were tested by One-sample Kolmogorov-Smirnov Formula (SPSS16.0 for Windows). To analyze the quantitative data, the researcher use Repeated Measure T-Test to find out the significant different of students' reading ability. Then, the researcher interpreted and concluded the T-Test data. Meanwhile, for qualitative data, the researcher did a close-ended questionnaire to find out students' responses toward the technique.

\section{RESULT AND DISCUSSION}

To address the first research question on students' reading ability, Repeated Measure T-Test was run. Based on the analysis, it can be seen that there is a significant difference of students' reading ability before and after the implementation of Mind Mapping Strategy as shown in the following table 1:

Table 1. Distribution of Students' Score of Pretest and Posttest

\begin{tabular}{|llllll|}
\hline & & Mean & N & Std. Deviation & Std. Error Mean \\
\hline \multirow{2}{*}{ Pair 1 } & Pretest & 30.726 & 31 & 8.3963 & 1.5080 \\
\cline { 2 - 6 } & Posttest & 57.823 & 31 & 6.9744 & 1.2526 \\
\hline
\end{tabular}

From Table 1, it can be seen that the students' mean score improves from pretest to posttest, that is, from 30.726 to 57.823 . The gain scores, that is, the improvement of the mean score of the pretest and posttest is 13.13. Besides, it can be seen that the Mind Mapping Strategy can also improve the students' reading ability.

Table 2. Hypotesis Testing

\begin{tabular}{|c|c|c|c|c|c|c|c|c|}
\hline & & \multicolumn{4}{|c|}{ Paired Differences } & \multirow{3}{*}{\multicolumn{2}{|c|}{$\mathrm{T} \quad \mathrm{df}$}} & \multirow{3}{*}{$\begin{array}{l}\text { Sig. (2- } \\
\text { tailed) }\end{array}$} \\
\hline & & \multirow[t]{2}{*}{ Mean } & \multirow[t]{2}{*}{$\begin{array}{l}\text { Std. } \\
\text { Devi } \\
\text { ation }\end{array}$} & \multirow[t]{2}{*}{$\begin{array}{l}\text { Std. } \\
\text { Error } \\
\text { Mean }\end{array}$} & $\begin{array}{l}95 \% \text { Confidence } \\
\text { Interval of the } \\
\text { Difference }\end{array}$ & & & \\
\hline & & & & & Lower & & & \\
\hline Pair 1 & $\begin{array}{l}\text { Pretest } \\
\text { Posttest }\end{array}$ & -27.0968 & $\begin{array}{l}2.50 \\
81\end{array}$ & .4505 & $\begin{array}{ll}-28.0167 & -26.1768\end{array}$ & $\begin{array}{l}- \\
60.154\end{array}$ & 30 & .000 \\
\hline
\end{tabular}

Table 2 above shows that significance value is 0.000 while $\alpha$ is 0.05 . It means that $0.000<0.05$. This indicates that the research hypothesis is accepted, that is, there is an improvement of students' reading ability before and after being taught by using Mind Mapping Strategy. 
To answer to the second research question about students' responses on toward Mind Mapping Strategy, the researcher used qualitative approach by giving the questionnaire to trace their responses. The researcher provides ten questions; there are two categories of questionnaire to bring up students' responses - comprehension and interest. For the coding purpose, the researcher used the following Likert's scale for each statement: (4) meaning strongly agree, (3) agree, (2) disagree and (1) strongly disagree toward the use of mind mapping strategy. The results of the fata analysis of students' responses are presented below:

Table 3 Students' Responses Toward Mind Mapping Strategy

\begin{tabular}{|c|c|c|c|c|c|c|}
\hline \multirow[b]{2}{*}{$\begin{array}{l}\text { Items' } \\
\text { Number }\end{array}$} & \multicolumn{6}{|l|}{ Answer } \\
\hline & $\begin{array}{l}\text { Strongly } \\
\text { Agree }\end{array}$ & Agree & Disagree & $\begin{array}{l}\text { Strongly } \\
\text { Disagree }\end{array}$ & Percentage & Categories \\
\hline 1. & 23 & 7 & 1 & 0 & $74.2 \%$ & \multirow{5}{*}{ Comprehension } \\
\hline 2. & 19 & 12 & 0 & 0 & $61.3 \%$ & \\
\hline 3. & 18 & 10 & 1 & 2 & $58.1 \%$ & \\
\hline 4. & 19 & 12 & 0 & 0 & $61.3 \%$ & \\
\hline 5. & 24 & 6 & 1 & 0 & $77.4 \%$ & \\
\hline Total & & & & & $66.46 \%$ & \\
\hline 6. & 16 & 14 & 0 & 1 & $51.6 \%$ & \multirow{5}{*}{ Interest } \\
\hline 7. & 11 & 16 & 1 & 3 & $35.5 \%$ & \\
\hline 8. & 21 & 10 & 0 & 0 & $67.7 \%$ & \\
\hline 9. & 20 & 8 & 2 & 1 & $64.5 \%$ & \\
\hline 10. & 15 & 16 & 0 & 0 & $48.4 \%$ & \\
\hline Total & & & & & $53.54 \%$ & \\
\hline
\end{tabular}

Table 3 shows the result of each category. The researcher analyzed and identified students' responses by using the questionnaire. Then, from the table above, it can be seen that all students' Mind Mapping Strategy has an easy way to follow. Besides, $100 \%$ of the students agree that they have no difficulties in teaching learning process while this technique is implemented and this method makes them enjoy and happy while the rest said that this method makes them feel bored.

\section{Discussion}

\section{Discussion of the Students' Reading Improvement}

The result of this research shows that students' reading ability improved after being taught by using Mind Mapping Strategy. This is proved by the improvement of students' posttest after they got treatment through Mind Mapping Strategy. The mean score of students' pretest was 30.726 and this score improved in the posttest after they got treatments in teaching learning process of reading by using Mind Mapping Strategy. The mean score that the students got for posttest was 57.823 where the improvement was 13,13 points and this way influenced by Mind Mapping Strategy.

On the other hand, this research is contrary with a research which was conducted by(Amalia, 2008), where the objective of her study is to find out the effectiveness of using mind mapping in 
improving students' reading comprehension achievement. It is a pre-experimental study which uses random sampling in getting the sample. The collecting data is only through the test. The result indicates that using mind mapping in teaching reading comprehension is effective to improve student's reading comprehension achievement. It can be seen from the result of pre-test and post-test; the average score of pre-test $=12.6$ and the standard deviation $=8.88$. Meanwhile, the average score of post-test $=21.7$ and the standard deviation $=9$.

\section{Discussion of Students' Responses}

The questionnaire was conducted with 31 of 31 participants after the implementation of Mind Mapping Strategy was administered. From the result of questionnaire, it found that majority of the students had positive responses toward Mind Mapping Strategy.

First, most of the students reveal that doing the reading exercise in descriptive text becomes easier. Since this strategy provides more challenging and interesting activities, the students are more actively and more creatively engaged in thinking. Then, the majority of students commented that they were relaxed during performing their English reading because this strategy was not boring. These findings suggest that having a good strategy may play an important role in facilitating the students.

Besides, almost all students agree that they are successful in learning process because there are question steps in Mind Mapping Strategy that help them to understand the material easily. Although they said that they were successful in learning process because of "question" step in Mind Mapping Strategy, the reason they were interested was not because of that "question" step, but because of other things such as this technique was fun and enjoyable.

Furthermore, a number of students said that they were motivated in learning English and they wanted to use this technique again because they could get new knowledge and they felt that question stepsused in Mind Mapping Strategy made them easier to learn English.

From the explanations above, it can be concluded that almost all students positively responded to the implementation of Mind Mapping Strategy in teaching and learning reading. This indicates that Mind Mapping Strategy builds a positive thinking in students' responses.

\section{CONCLUSIONS AND SUGGESTIONS}

Based on the results of the data analysis and discussion, the following conclusions are drawn: First, there was a significant difference of students' reading comprehension ability before and after the implementation of Mind Mapping Strategy in teaching and learning reading. Secondly, almost all students positively responded to the use of Mind Mapping Strategy in teaching and learning reading comprehension because they felt they were relaxed, and enjoyed the learning process from the beginning through the end of the reading session. Regarding the finding of the research, the researcher would like to present some suggestions. First, it is suggested that English teachers should use Mind Mapping Strategy to make learning processchallenging. Second, since the technique is a kind of question steps, it enables the class to become noisy. So the teacher's supervision is needed in the implementation of the technique. The teacher should be creative and active to guide the students in the learning process using Mind Mapping Strategy. Then, the teacher should monitor the students so that the students become active and 
effective. Last, the technique took a lot of time in the implementation. So, the teacher should consider time management in implementing Mind Mapping Strategy.

Considering the limitation of the research, the researcher recommends for further research. First, this study was conducted in the first grade of junior high school. Therefore, the further researcher should try to find out the use of Mind Mapping strategy in different levels of school and to improve the other English skills. Second, it is suggested for further researcher to give a try out test before conducting pretest and posttest. So, the test of pretest and posttest will be approprite with the students' knowledge. Last, it is also suggested for further researcher to conduct the treatment for more than three meetings to get more accurate data.

\section{REFERENCES}

Ana, Amalia. (2008). Teaching Reading Comprehension Through Mind Mapping: A Case of The Eleventh Grade Students of SMA N 2 Demak in the academic year 2008/2009, (Skripsi,Faculty of Language and Art Education, IKIP PGRI Semarang).

Buzan. (2000). The international journal of indian psychology. Effectiveness of Teaching Through Mind Mapping Technique (3), No.3, April-June 2016, 149-156.

Buzan.(2006). SEMDI UNAYA.Improving Students' Reading Comprehension Through Mind Mapping. November 2017, 315-318.

Corbett, W. 1983.The Little Rhetoric and Handbook with Reading. Bloomington, Illinois: Scott, Freshman.

Durkin, D. (1993). Teaching them to read (6th Ed.). Boston: Allyn\& Bacon.

Grabe, W. (2009).Reading in second language: Moving from theory to practice. New York, NY: Cambridge University Press.

Ingemann. (2008). English language teaching and research. Utilizing Mind Mapping as Assessment Tool For Reading Comprehension. I (I), 152-163.

Kane, T.S. (2000). Essential Guide to Writing. Oxford: 2000. Oxford University Press.

Mikulecky, Beatrices. 2011. A Short Course in Teaching Reading. New York: Pearson Education.

Suparman, U. 2011. The implementation of iteman to improve the quality of English test items as a foreign language: An assessment analysis. AKSARA-JurnalBahasa, Seni, danPengajarannya, 2011, 12 (1), pp. 86-96.

Suparman, U., Ridwan, R. \& Hariri, H. 2020a. Promoting Learning Performance and Learning Outcomes: The Case of an Indonesian School. The Asian EFL Journal, October 2020, Volume 27, Issue 4.1, pp. 94-110. https://www.asian-efl-journal.com/monthly-editionsnew/2020-monthly-editions/volume-27-issue-4-1-october-2020/

Suparman, U., Ridwan, R. \& Hariri, H. 2020b. Overcoming Students' English Pronunciation in Remote Area, Indonesia.The Asian EFL Journal, October 2020, Volume 27, Issue 4.1, pp. 94-110. https://www.asian-efl-journal.com/monthly-editions-new/2020-monthlyeditions/volume-27-issue-4-1-october-2020/

Suparman, U., Hariri, H., Haenila, E.Y., \&Usman, M. 2020c. Completely randomized block design for assessment of the gender and personality effect on reading comprehension ability.Journal of Southwest Jiaotong University, Vol. 55 No. 4 Aug. 2020, pp. 1-14. DOI: 10.35741/issn.0258-2724.55.4.21. http://jsju.org/index.php/journal/article/view/666 